\title{
ЛІНГВІСТИЧНА ШКОЛА ДОКТОРА ФІЛОЛОГІЧНИХ НАУК, ПРОФЕСОРА С. І. ДОРОШЕНКА
}

Стаття присвячена 95-літньому ювілею доктора філологічних наук, професора, заслуженого діяча науки і техніки Украӥни Сергія Івановича Дорошенка (Харківський національний педагогічний університет імені Г. С. Сковороди), містить інформацію про лінгвістичну школу видатного педагога та філолога, зокрема окреслено основні напрямки дослідницької діяльності С. І. Дорошенка та його учнів в царині національного мовознавства та лінгводидактики кін. ХХ - поч. ХХІ століття. У роботі подано огляд дисертаційних досліджень аспірантів видатного мовознавия, де коротко репрезентовано основні напрацювання в галузях лінгвістики та лінгводидактики. Сергій Іванович - видатний учений-україніст, який понад 65 років свого життя присвятив науково-педагогічній діяльності у вищій школі. Його праці із сучасної української мови і культури та методики ї викладання відомі в усій Україні й за ї̈межами. Його наукові учні й послідовники працюють у різних регіонах України, Свропи, США. Своєю невтомною працею, життєлюбством, доброю вдачею наш Учитель зігрівав серия всім, хто з ним спілкувався, щедро віддавав свої знання колегам і студентам, відкривав золоту браму в дивовижний світ мовознавства. Він завжди випромінював позитивний заряд, іскорки гумору, перлинки мовних скарбів.

Ключові слова: лінгвістична школа, Дорошенко, учитель, наставник, мовознавство, стилістика, граматика, синтаксис, складні речення, безсполучникові складні речення, предикативні одиниці, методика викладання філологічних дисциплін.

Chernushenko Nina. Linguistic school of doctor of philological sciences, professor Sergiy Doroshenko. The article is dedicated to the $95^{\text {th }}$ anniversary of doctor of philological sciences, professor, honored scientist and technician of Ukraine, Sergiy Doroshenko (Kharkiv State Pedagogic University named after Grygoriy Skovoroda), contains the information about linguistic school of the prominent teacher and philologist, the main points of his and his students' research in the field of linguistics and linguodidactics at the end of XX-beginning of XXI century. The paper gives an overview of the dissertation researches of post-graduate students of the outstanding linguist, where the main findings in the branches of linguistics and linguodidactics are briefly represented..Sergiy Ivanovich is a prominent Ukrainian scholar, who has dedicated more than 65 years of his life to scientific and pedagogical activity at high school. His works on contemporary Ukrainian language, culture and teaching methods are well-known across Ukraine and abroad. His scientific students and followers work in different regions of Ukraine, Europe, and the USA. Through his tireless work, love to life, good temper our Teacher warmed the hearts of all who talked to him, generously gave his knowledge to colleagues and students, opened the golden gate into the wonderful world of linguistics. He has always radiated a positive charge, sparkles of humor, and pearls of language treasures.

Key words: linguistic school, Doroshenko, teacher, mentor, linguistics, stylistics, grammar, syntax, complex sentences, conjunctionless complex sentences, predicative units, philological disciplines teaching methods.

Лінгвістична школа професора С. I Дорошенка почала формуватися на початку 80-х років минулого століття. Ідеї в царині стилістики, граматики, лінгвостилістики зазнали еволюції в наукових дослідженнях його учнів, що й зумовило формування наукової школи відомого мовознавця не лише в Україні, а й у далекому зарубіжжі. Після успішного захисту докторської дисертації «Безсполучникові складні речення в сучасній українській мові» 
Сергій Іванович очолював кафедру методики викладання філологічних дисциплін у початковій школі в Харківському державному педагогічному інституті імені Г. С. Сковороди, де і працювала викладачем української мови $Г а-$ мова Ганна Іванівна. Саме вона стала першою аспіранткою С. I. Дорошенка зі спеціальності «українська мова». Тему дисертаційного дослідження було обрано як поглиблення проблеми, над якою працювала кафедра української мови, а саме із синтаксису складного та простого речення в сучасній українській мові. У роботі розглядалися способи вираження мети на різних синтаксичних рівнях. Дисертаційна робота була успішно завершена і захищена в 1989 році в спеціалізованій раді Харківського державного університету (Нині ХНУ ім. В. Н. Каразіна). Оскільки в той час нормативною базою ВАК було визначено, що всі дисертаційні роботи виконувались російською мовою, то тема теж затверджувалась російською мовою: «Синтаксическое выражение цели в современном украинском литературном языке». У роботі Г. І. Гамової представлені в найбільш повному висвітленні засоби оформлення цільових відношень у простому, складному реченнях і в надфразних єдностях (складних синтаксичних цілих) сучасної української мови як самостійні мікросистеми. У результаті проведених на широкому фактичному матеріалі спостережень Ганна Іванівна підтвердила теоретичне положення про взаємозв'язок компонентів різних мовних рівнів: лексичного і граматичного. Разом із тим розширено реєстр прислівників мети, розкрито специфіку створення обставин мети з використанням дієприслівникового звороту, збільшено перелік складених прийменників і сполучників, використовуваних для оформлення цільових структур; засвідчено, що у визначенні обставини мети слід спиратися на семантику компонента вираження цілі (опорні слова й лексеми із цільовою семантикою). Крім того, виявлено ознаки нейтралізації синкретизму в іменниково-співвідносних формах у залежності від дієслова, іменника та наявності / відсутності просторового чи об'єктного компонента; доведено неправомірність визнання того, що обставина мети перебуває в залежності від дієслів із семантикою руху: у ролі опорного слова щодо мети виступають різні форми дієслів, слова категорії стану й прикметники. Аргументовано доведено, що розташування головної й підрядної частин в реченнях мети не може визнаватися вільним, виявлені позиційні обмеження цього. Фіксований порядок розташування предикативних одиниць у безсполучникових складних реченнях, заснований на часово-способовому вираженні предикатів, є свідченням самостійності безсполучникових складних конструкцій із цільовою семантикою як виду складних конструкцій, а не безсполучникового різновиду складнопідрядних речень мети. Представлені в дослідженні спостереження й висновки довели, що описані способи вираження мети не становлять закритої системи, а розширення граматичних засобів вираження мети репрезентують процес ускладнення системи оформлення цільового значення в межах синтаксичної мікросистеми (Гамова, 1989).

Г. І. Гамова більше 20 років працювала на кафедрі, яку свого часу заснував професор С. І. Дорошенко на факультеті початкового навчання. А 32002 
по 2005 рік була завідувачем кафедри теорії та методики викладання філологічних дисциплін у початковій школі. Зараз Ганна Іванівна працює професором на кафедрі української мови в Харківському регіональному інституті державного управління Національної академії державного управління при Президентові України та продовжує традиції свого видатного Учителя.

У 1984 році до наукової школи С. І. Дорошенка приєдналася викладач Полтавського державного педагогічного інституту імені В. Г. Короленка Алексеюк Марія Йосипівна. Вона стала пошукачкою кафедри української мови ХДПІ імені Г. С. Сковороди. Свою дисертацію «Предикативные наименования лиц в современном украинском языке» присвятила вивченню раніше не досліджуваного в лінгвістичній україністиці питання предикативного найменування осіб. Для дослідження специфіки будови й функціювання предикативних одиниць було залучено тексти різних стилів сучасної мови, у результаті їхнього аналізу було виявлено й схарактеризовано основні ознаки компонентів предикативного найменування осіб; установлено конкретний набір структурних моделей таких найменувань осіб. Вивчення предикативних найменувань осіб здійснювалося з урахуванням розрізнення понять «мова» $\mathrm{i}$ «мовлення». Дослідження предикативних найменувань осіб на матеріалі кодифікованої літературної мови й усного розмовного мовлення дозволило виявити не лише компенсаторні властивості синтаксичних найменувань, але й значно більші, ніж у лексичних найменувань, парадигматичні, синтагматичні, стилістичні можливості. Значущість дослідження в тому, що його спостереження й висновки можуть бути використані, поперше, у подальшому вивченні загальних закономірностей і тенденцій розвитку номінативної системи української мови взагалі, і питань синтаксичної номінації зокрема; по-друге, у розкритті особливостей слова і словосполучення як засобу номінації в порівнянні із синтаксичними найменуваннями (Алексеюк, 1988).

Наступною аспіранткою Сергія Івановича стала викладачка кафедри англійської мови нашого вишу Степул Оксана Леонідівна. Тема ії̈ роботи була логічним продовженням проблеми, над якою працював професор Дорошенко, а саме «Безсполучникові складні речення із значенням зіставності і протиставності в українській мові» (1992р.). Дисертаційне дослідження стало першим в україністиці монографічним вивченням безсполучникових складних речень зі значенням зіставності й протиставності. Унаслідок проведеного пошуку й на підставі врахування семантичного розрізнення понять зіставності / протиставності визначено їхню нетотожність і взаємну непідпорядкованість, на основі чого обгрунтовано самостійність розглядуваних у дисертації видів безсполучникових складних конструкцій. Було доведено правомірність вилучення безсполучникових складних речень із значенням зіставності / протиставності з розряду речень однорідного (однотипного) складу, до яких, крім них (за класифікацією М. С. Поспєлова) належать речення перелічувальної семантики. Перелічуваність базується на семантично однорідному відношенні предикативних частин. Зіставність / протиставність не становлять переліку, тому не можуть бути віднесені до цього 
розряду речень. Вони не припускають розширення будови. Це означає, що їм властива закритість структури, тим часом, як речення переліку характеризуються відкритістю структури.

Цінність висновків і спостережень, представлених у роботі, передусім полягає в тому, що в ній уперше в україністиці репрезентовано узагальнені дані семантичного й граматичного розгляду понять зіставності й протиставності; проаналізовано будову безсполучникових складних зіставних і протиставних речень із застосуванням понять закритості / відкритості структур, на основі чого виявлено властиві їм специфічні риси; подано класифікацію їхніх різновидів і з'ясовано стилістичне функціонування кожного з них. Теоретично обгрунтоване положення про правомірність вилучення безсполучникових складних речень із значенням зіставності й протиставності з розряду структур однорідного (однотипного) складу є вагомим поштовхом для перегляду поширеної сьогодні у вишівських і шкільних підручниках класифікації безсполучникових складних речень, яка не відбиває справжній стан синтаксичної системи української мови (Степул, 1992). Цю роботу Оксана Леонідівна захистила в новій раді ХДПІ імені Г. С. Сковороди в 1992 році, вона була написана українською мовою. Зараз Оксана Леонідівна разом із родиною проживає в місті Денвері, штат Колорадо (США), займається перекладацькою діяльністю та надає мовні консультації з різних мов своїм співвітчизникам.

Із 1991 року викладачка кафедри англійської мови педагогічного інституту Глотова Олена Василівна почала працювати над дисертацією «Функціонально-синтаксичний аналіз категорії причиновості в сучасній українській літературній мові». Дослідження було здійснене із застосуванням функціонального підходу до аналізу категорії причиновості як процесу відображення взаємозв'язку й взаємозумовленості процесів і явищ об'єктивної дійсності. Такий підхід був новим не тільки для україністики, а й для всього східнослов'янського мовознавства й дозволив у функціональному плані розглянути весь комплекс реалізації причинових відношень в одиницях різного ступеня складності в простому й складному реченні та поставити питання про встановлення ієрархії синтаксичних одиниць, які формують причиновість. Результативність роботи визначається одержанням додаткових даних для розв'язання важливих проблем теорії функціонального синтаксису, а саме: для розмежування семантико-синтаксичних і формально-синтаксичних функцій синтаксичних одиниць, що виражають причиновість, зокрема, серед набору синтаксичних одиниць причини виділено граматичні, граматизовані й неграматизовані структури. Разом з тим з'ясування рис функціонально-семантичного поля причиновості уможливило виявлення всього ланцюга взаємопов'язаних різнорівневих засобів категорії причиновості. У ході дослідження доведено також, що стилістична диференціація мови як одного із проявів еволюції мовної системи в цілому зумовлюється дією екстралінвальних факторів, потребами в розвитку семантичної структури мови. Представлене в роботі ієрархічне групування мовних засобів причиновості слугує моделлю для зіставного і типологічного опису причиновості 
у споріднених мовах. Своє дослідження Олена Василівна успішно захистила в 1994 році (Глотова, 1994). Учениця Сергія Івановича тривалий час очолювала кафедру практики англійського усного та писемного мовлення на факультеті іноземної філології ХНПУ імені Г. С. Сковороди, на якій працює й зараз.

На початку 90-х років при кафедрі методики викладання філологічних дисциплін нашого університету, яку заснував С. І. Дорошенко, було відкрито аспірантуру зі спеціальності «методика викладання української мови». Однією з перших аспіранток із цієї спеціальності стала директор середньої школи № 23 м. Харкова Черновол-Ткаченко Раїса Іванівна. Її робота присвячена формуванню орфографічної грамотності з української мови в російськомовних першокласників. У дисертації розроблена система формування орфографічних й орфоепічних умінь і навичок української мови в російськомовних учнів початкової школи. У результаті проведеного експерименту доведено, що ефективне розв'язання проблеми формування орфографічних навичок у російськомовних першокласників, які вивчають українську мову як першу, має, по-перше, спиратися на навчальну програму, яка передбачає вивчення відомостей з фонетики, орфоепії й орфографії паралельно з опрацюванням інших розділів курсу української мови, а, по-друге, формувати орфографічні навички здійснювати не шляхом заучування розрізнених правил, а на грунті засвоєння фонетичних знань і орфоепічних умінь, тобто через усвідомлене освоєння правописних норм на основі правильної літературної вимови. Крім того, в роботі поставлено питання про правомірність уведення в навчальний процес поряд із освоєнням орфограм, що грунтуються на літературній вимові, роботи з орфограмами, розпізнавальні ознаки яких зумовлені усним мовленням російськомовних учнів. Наведені дані засвідчили позитивні результати застосування експериментальної методики навчання першокласників (Черновол-Ткаченко, 1995). Ця робота, якою з натхненням керував С. І. Дорошенко, була захищена в Києві в Інституті педагогіки АПН України в 1995 році. Після захисту кандидатської дисертації Раїса Іванівна перейшла працювати до ХДПУ імені Г. С. Сковороди в Інститут післядипломної освіти, який нині очолює. Керує роботою аспірантів, має велику кількість наукових публікацій з менеджменту освіти та педагогіки.

Розширюючи проблематику методики викладання української мови в початковій школі, аспірантка з ПДПІ ім. В. Г. Короленка Олійник Світлана Петрівна працювала над роботою «Осмислене письмо за зразком як засіб формування правописних навичок у першокласників». Узагальнення й висновки дисертаційного дослідження, здійснені на основі проведеного експерименту, дозволили визнати правомірність і доцільність уведення в систему навчання грамоти осмисленого письма за зразком як початкового етапу в розвитку орфографічних і пунктуаційних дій молодших школярів і як засобу формування в них правописних навичок. Застосування осмисленого письма за зразком здійснюється паралельно з роботою над каліграфією й бере свій початок зі списування складів і слів, передбаченого зошитами з 
друкованою основою. Його мета - задовольнити потребу в активізації орфографічних і пунктуаційних дій, виробленні навичок правописної пильності з перших кроків виконання письмових вправ, побудованих на списуванні слів, словосполучень, речень і тексту. Специфіка методики полягає в тому, що навички грамотного письма формуються без заучування орфографічних та пунктуаційних правил. Розкриття лінгвістичної природи орфографічних явищ з урахуванням графіки української мови зумовило потребу введення узагальненого поняття орфограми на етапі навчання грамоти, а також окремих правил уживання розділових знаків. Практично досягти цього можна лише за умови вироблення навичок виконання послідовних вимог до ознайомлення із зразком, який підлягає списуванню. Розроблена методика грунтується на засадах психологічних теорій про засвоєння знань і вироблення навичок у процесі активної діяльності, поетапне формування розумових дій, урахування вікових й індивідуальних особливостей школярів (Олійник, 1995). Ця дисертація також була успішно завершена й захищена в 1995 році в м. Києві в Інституті педагогіки АПН України. Після закінчення аспірантури в Харкові Світлана Петрівна повернулася до Полтави, де й зараз працює в педагогічному університеті на посаді заступника декана з виховної роботи.

Вихованкою школи С. І. Дорошенка стала авторка цієї статті ( Ніна Миколаївна Чернушенко). Із Сергієм Івановичем я познайомилась у 1979 році, коли стала студенткою філологічного факультету ХДПІ імені Г. С. Сковороди (відділення української мови та літератури). На першому курсі мій майбутній науковий керівник викладав вступ до мовознавства. Пізніше, після закінчення інституту і 4-х років роботи у школі (в 1988 році), Сергій Іванович запросив мене на посаду викладача української мови на кафедру методики викладання філологічних дисциплін у початковій школі. Це було почесне й відповідальне доручення. Пропрацювавши кілька років на факультеті початкового навчання під керівництвом вельмишановного професора, я з радістю в 1991-му році приєдналась до аспірантів кафедри української мови. Черговою вершиною в житті, яку треба було подолати, стала дисертація на тему «Безсполучникові умовно-наслідкові речення в функціонально-синтаксичному аспекті». Тему дисертації обирав Сергій Іванович, оскільки було зрозуміло, що авторитетна думка шановного професора $є$ найвагомішою.

Значущість дисертаційного дослідження, створеного під керівництвом відомого мовознавця, визначається тим, що в ньому вперше в синтаксичній науці східнослов'янських мов здійснена спроба дати різнобічний аналіз усіх різновидів умовно-наслідкових безсполучникових складних речень. У роботі був застосований новий підхід до вивчення названого виду складних структур: вони аналізуються в семантико-синтаксичному, формальносинтаксичному й функціональному планах, що служить обгрунтуванням реченнєвого, а не текстового характеру умовно-наслідкових безсполучникових складних структур як комунікативних одиниць мови. I цей новаторський підхід був можливим лише за підтримки мого наукового керівника. За семантико-синтаксичними ознаками аналізовані складні конструкції 
поділяються на потенційно-умовні й ірреально-умовні речення. Модальне розрізнення цих структур визначає форма предиката зумовленої частини. Новим є обгрунтування здатності дієслівної форми умовного способу, яка в ролі предиката зумовлюючої предикативної частини співвідноситься в зумовленій із формами умовного способу (чи інфінітивом з би (б)) або майбутнього часу, бути граматичним показником підрядного зв'язку. Виявлення нових ознак граматичної природи форми умовного способу, завдяки яким реалізується граматичний зв'язок підрядності в окремих моделях умовно-наслідкових безсполучникових складних реченнях, розширює наукове розуміння безсполучниковості. Практичне значення дослідження визначається передусім повним описом цього виду складних безсполучникових конструкцій, а також значним фактичним матеріалом, дібраним з різних стилів української мови, джерел української усної народної творчості. Робота була завершена й успішно захищена в червні 1995 року (Чернушенко, 1995). Відчуваючи постійну підтримку з боку видатного вченого й наставника, я розпочала працювати над докторською дисертацією, яка присвячена експресивним одиницям синтаксису в художній літературі XX століття, закінчила докторантуру й нині продовжую працювати на кафедрі, засновником якої був наш дорогий Сергій Іванович. До джерел лінгвістичної школи нашого Учителя долучилася й моя аспірантка Лелюк Олена Олександрівна, яка у своїй роботі дослідила стилістику й прагматику синтаксичних конструкцій із підрядним компонентом причини в українській художній прозі 90-х років XX - початку XXI століття (Лелюк, 2018).

Із 1949 року C. I. Дорошенко тривалий час працював викладачем, а пізніше проректором в Сумському державному педагогічному інституті імені А. С. Макаренка, а тому не дивно, що до когорти аспірантів долучилися й викладачі цього вишу. Беценко Тетяна Петрівна обрала об'єктом свого дослідження структуру й поетичну функцію атрибутивних словосполучень у поезіях шістдесятників (1999 р.). Дослідження теми було здійснене в межах синтаксичної стилістики й присвячене висвітленню однієї з маловивчених у лінгвістичній україністиці проблем: аналізові мінімальних синтаксичних конструкцій - атрибутивних словосполучень типу «прикметник + іменник» - у віршовій мові, зокрема в поетичних текстах шістдесятників М. Вінграновського, П. Засенка, Л. Костенко, Д. Павличка, В. Симоненка, В. Стуса. Аналіз атрибутивних синтаксичних одиниць у поезіях шістдесятників диктувалося прагненням пізнати специфіку одного із жанрів художньої літератури - поезії, де сконденсованість висловлення потребує пошуків у компонентах словосполучення яскравих семантичних граней для оформлення задуму, виявлення естетичних функцій мови, спостереження над якою становить одне із завдань сучасної лінгвістики. У коло досліджуваних питань входить спостереження за особливостями функціонування іменників і прикметників як складників атрибутивного словосполучення, встановлення ролі кожного з компонентів у творенні художніх образів поетами-шістдесятниками, виявлення синтаксичних новотворів за існуючою в українській мові моделлю «прикметник + іменник». Зокрема доведено, що чим більше 
відмінного в сполучуваних словах, тим яскравіший образ, заснований на метафоричних чи метонімічних зв'язках (Беценко, 1999). Тетяна Петрівна захистила докторську дисертацію, здобула звання професора й зараз працює на кафедрі української мови та літератури в СДПУ імені А. С. Макаренка.

Загревський Євген Іванович - випускник українського мовно-літературного факультету, розпочав свою педагогічну діяльність у школі, а згодом був запрошений на посаду викладача кафедри української мови. Молодий науковець виявив бажання займатися дослідженням безсполучникових речень. Згодом був обраний і предмет дослідження, а саме безсполучникові складні речення з пояснювальним компонентом у сучасній українській мові (1999 р.). Дисертаційне дослідження репрезентує першу в українському мовознавстві монографічну спробу вивчення семантико-синтаксичних особливостей пояснювальних відношень у структурі безсполучникових речень, що мало своїм наслідком повний опис цього виду безсполучникових складних речень на основі фактичного матеріалу, дібраного з різних стилів української мови.

У дисертації визначено зміст «пояснення» стосовно безсполучникових конструкцій; усебічно розкрито особливості структурної організації їх окремих різновидів, що дозволило уточнити класифікацію безсполучникових пояснювальних речень, зокрема запропоновано нову класифікацію пояснювальних безсполучникових складних речень, доповнено й уточнено твердження I. Р. Вихованця про наявність підрядного зв'язку між предикативними частинами окремих різновидів безсполучникових складних структур з пояснювальним компонентом; на основі підрахунків доведено широке їх функціювання в різних сферах української мови як засобу усного й писемного спілкування, що має сприяти розв'язанню ряду важливих проблем безсполучниковості. На основі здійсненого аналізу семантичної й граматичної співвіднесеності досліджуваних і сполучникових конструкцій констатовано, що речення обох типів виявляють як спільні, так і специфічні риси граматичності. Проведено дослідження поширеності й частотності безсполучникових складних речень з пояснювальними відношеннями компонентів у стилях мови й доведено їхнє широке функціонування в різних сферах використання сучасної української мови (Загревський, 1999). Євген Іванович тривалий час займався викладацькою роботою, а згодом став науковим співробітником проекту «Інтелект України».

Кринська Наталія Володимирівна працювала над дисертацією «Семантико-синтаксична категорія наслідку в складному реченні в книжних стилях сучасної української мови», яку успішно захистила в 2001 році. Роботу визначає те, що в ній уперше в лінгвістичній україністиці здійснено цілісний аналіз синтаксичної категорії наслідку в ії формально-змістовій єдності на рівні складного речення; виявлено граматичні й семантичні засоби передачі наслідку в складних реченнях різних типів (складносурядних, складнопідрядних і безсполучникових); уточнені характеристичні (структурні й стилістичні) особливості безсполучникових складних речень з наслідковим компонентом. 
Теоретична цінність праці полягає в одержанні нових даних про граматичні й семантичні засоби оформлення відношення причини й наслідку в різних структурах складних речень, що розширює наукову характеристику складних речень з компонентом наслідку й відкриває перспективу їх подальшого вивчення. Крім того, обгрунтовано наявність у сучасній українській літературній мові новостворених підрядних наслідкових сполучників внаслідок чого, в результаті чого, від чого, завдяки чому, через що, поширених у книжних стилях як засобів поєднання предикативних частин складнопідрядних речень наслідку, і слів та прийменниково-займенникових сполук тому, значить, звідси, отже, в результаті, внаслідок, таким чином, в результаті цього, внаслідок цього, завдяки иьому, через це (те), від цього (того), які в межах складносурядних і безсполучникових речень функціонують як експлікатори наслідку, активне використання новотворів відбиває одну з важливих тенденцій у розвитку мови - прагнення до розщеплення засобів чіткої й однозначної передачі причиново-наслідкового відношення в системі складних речень української мови (Кринська, 2001). Наталія Володимирівна до Дня народження нашого Учителя видала монографію «Структурно-семантичний синтаксис: складні речення з компонентом наслідку», підготовлену у співавторстві із ним.

Мясоєдова Світлана Вадимівна обрала тему для дисертації «Категорія спонукання і ії вираження в непрямих висловленнях сучасної української мови» (2001 р.) У дисертації вперше в українському мовознавстві на широкому фактичному матеріалі здійснено системний аналіз непрямих спонукальних висловлювань із урахуванням їхніх структурно-граматичних, лексико-семантичних і комунікативно-прагматичних особливостей; установлено семантичні й прагматичні критерії розрізнення відтінків спонукального значення; виявлено диференційні ознаки основних його різновидів; описано мовний механізм імпліцитного вираження спонукання, а також зв'язок імпліцитних спонукальних висловлень із контекстом і конситуацією. Дослідження визначається висновками й узагальненнями, що сприяють глибшому пізнанню категорійних особливостей української мови, доповнюють учення про типи речень за цілеспрямованістю положень про непрямі способи вираження спонукання у структурі висловлень української мови й слугуватимуть подальшому осмисленню певних теоретичних питань функціонального синтаксису, семантики й стилістики. Разом з тим у роботі репрезентовано повний опис засобів вираження непрямого спонукання у висловленнях української мови; визначено чинники формування й критерії розрізнення його окремих різновидів, які не тільки забезпечують процес мовної комунікації, а й визначають його естетичну цінність; доведено, що непрямі спонукальні висловлення становлять виразний засіб вираження категорії спонукання, який відповідає різноманітним комунікативним завданням, зокрема вираженню спонукання не в прямий спосіб, тобто без залучення дієслівних форм імператива, уможливлює збільшення іллокутивної сили висловлення (Мясоєдова, 2001). Світлана Вадимівна працює доцентом кафедри іноземних мов № 3 Національного юридичного університету імені Ярослава Мудрого в м. Харкові. 
Телєжкіна Олеся Олександрівна - випускниця Сумського державного педагогічного університету імені А. С. Макаренка. Після завершення навчання в інституті кілька років працювала в гімназії м. Сум, а потім викладачем кафедри української мови та зарубіжної літератури СДУ. Спочатку Олеся Олександрівна була пошукачкою на кафедрі української мови ХДПУ імені Г. С. Сковороди, а потім вступила до аспірантури. Тема дисертації продовжила традиції школи професора С. І. Дорошенка, вона присвячена безсполучниковим складним реченням з компонентом обгрунтування й була захищена в 2002 році. Ця дисертація є першим в синтаксичній науці монографічним дослідженням безсполучникових складних речень з відношенням обгрунтування між предикативними компонентами. У роботі вперше сформульовані ознаки безсполучникових складних речень із компонентом обгрунтування як окремого виду синтаксичних одиниць у системі складних безсполучникових конструкцій із відношенням детермінації; розкрито зміст поняття «обгрунтування» в застосуванні до безсполучникових складних речень; запропоновано нові підходи до їхньої класифікації. Зокрема, доповнено й конкретизовано класифікацію безсполучникових структур різнофункціонального типу, яка грунтується, по-перше, на врахуванні семантико-граматичного оформлення першої частини у ній репрезентовано факт, подію, явище, i, по-друге, на смисловому наповненні всієї єдності. Здійснений аналіз дозволив констатувати, що саме розміщення предикативних частин визначає структурно-семантичну специфіку цього виду безсполучникових речень, за якою друга частина виконує обгрунтовувальну функцію: функцію вираження аргумента, підстави, мотиву, причини, того, про що йдеться в першому компоненті (Тєлєжкіна, 2002). Олеся Олександрівна видала монографію з теми свого дослідження. Зараз викладає українську мову за фахом студентам Національного фармацевтичного університету в м. Харкові та працює над докторською дисертацією «Мова української поезії другої половини XX - початку XXI століття».

Сергій Іванович Дорошенко завжди пишався своїм докторантом Андpiєм Івановичем Даниленком, який працює на посаді професора в університеті «Пейс» у Нью-Йорку. У наукових колах він відомий як автор грунтовного дослідження «Предикати, відмінки і діатези в українській мові: історичний і типологічний аспекти» (2003) і численних статей, надрукованих у наукових виданнях різних країн світу.

Зі своєю наступною аспіранткою Тетяною Василівною Бєляєвою Сергій Іванович познайомився в Інституті післядипломної освіти нашого університету в 1996 році, де пані Тетяна здобувала другу вищу освіту - учителя української мови та літератури. Тоді ніхто не міг передбачити, що ця зустріч стане доленосною для Тетяни Василівни. Після завершення аспірантури та захисту дисертації вона залишилась працювати на кафедрі української мови й розпочала викладати разом із Сергієм Івановичем курс «Вступ до мовознавства». Саме Тетяна Василівна продовжила традиції професора Дорошенка у викладанні цього й інших курсів української мови. Вона $є$ доцентом кафедри української мови й до останнього дня роботи Сергія Івановича 
в університеті працювала з ним пліч-о-пліч. Її наукова робота «Варіантність і синонімія в умовно-наслідкових складних реченнях» (2004 р.) присвячена розгляду проблеми варіантів і синонімів у трьох типах складних речень (складносурядних, складнопідрядних і безсполучникових) 3 відношенням умови й наслідку, що полягають у виявленні на основі формально-синтаксичного й семантико-синтаксичного підходів міжрівневих й однорівневих варіантних і синонімічних відношень з урахуванням граматичних і граматизованих засобів зв’язку предикативних частин, що є першою спробою такого теоретичного пояснення названих синтаксичних одиниць. В основу розрізнення цих понять покладено протиставлення видозмін, тотожних у модальному й структурному наповненні, спільних стильовою віднесеністю й стилістичними прикметами й одномодальних видозмін, близьких семантико-синтаксичним відношенням, але нетотожних формально-синтаксичними ознаками, стильовою належністю або стилістичним забарвленням: перші - синтаксичні варіанти, другі - синтаксичні синоніми. Значущість дисертаційного дослідження вбачається передусім у визначенні теоретично обгрунтованої опозиції модальних інваріантів у парадигмі різних типів складних речень з умовно-наслідковим відношенням; у виділенні розрізнювальних ознак синтаксичних варіантів і синтаксичних синонімів у розглядуваних складних реченнях; у доведенні неправомірності визнання сполучника раз умовним: названі прикмети на підтвердження його причинового характеру; у виділенні серед складнопідрядних речень умови групи власне умовного й обмежувально-умовного значення, що, зокрема, дозволило не розглядати в парадигмі варіантів і синонімів речень з відношенням умови й наслідку сполучника аби. Представлені в роботі спостереження доводять, що формування умовно-наслідкового значення, зокрема складносурядними й безсполучниковими складними структурами, підпорядковане розташуванню частин і часово-способовим відношенням присудків предикативних компонентів. Крім того, уживання транспонованого імператива в названих конструкціях уможливлює створення як варіантних, так і синонімічних відношень, що засвідчуються в різних міжрівневих й однорівневих синонімах 3 ознакою розмовності й виразної експресії (Бєляєва, 2004). Зараз Тетяна Василівна Бєляєва здійснює керівництво аспірантами, рецензування наукових і навчально-методичних видань. Вона секретар кафедрального наукового видання «Лінгвістичні дослідження», затвердженого ВАК України.

Ващенко Олена Іванівна захистила дисертацію на тему: «Валентна і невалентна сполучуваність відприкметникових іменників у сучасній українській мові» (2005 р.) У науковому дослідженні вперше висвітлено валентнісні властивості відад’єктивних іменників з урахуванням їхніх структурних і лексико-семантичних властивостей і доведено: валентністю наділені переважно абстрактні іменники-відад’єктиви, які пройшли морфологічний ступінь субстантивації на відміну від іменників з конкретним значенням, що найчастіше утворюються завдяки синтаксичній та / або семантичній транспозиції з прикметників, втрачаючи при цьому як предикативні знаки, так і валентні властивості. У роботі виявлено особливості валентної й невалентної 
сполучуваності відприкметникових іменників, синтаксичних зв'язків та семантико-синтаксичних відношень деад'єктивів із своїми поширювачами порівняно з валентнісними ознаками інших, зокрема непохідних, іменників. На основі врахування сполучувальних властивостей іменника як частини мови визначено спільні й відмінні риси сполучуваності непохідних іменників і відад'єктивних утворень. Визначено ступінь залежності вибору й умов реалізації синтаксичних зв'язків і семантико-синтаксичних відношень від їхньої граматичної сполучуваності. Значущість дослідження полягає в розкритті теоретичних засад валентної й невалентної сполучуваності іменників-відад'єктивів з урахуванням сполучувальних потенцій прикметників, від яких вони утворені, та сполучувальних можливостей іменників, до лексико-граматичного класу яких вони входять. Опрацьовані в дисертації теоретичні проблеми застосовані в мовознавчих розвідках із теорії словотвірних, морфологічних та синтаксичних категорій, взаємодії морфології й синтаксису, а також у дослідженні проблем функціональної граматики сучасної української мови (Ващенко, 2005).

Лисак Лариса Констянтинівна із м. Краматорська присвятила своє дослідження синтаксико-стилістичній функції речень з дієприслівником у стилях сучасної української мови (2007р.). Вагомість її дисертаційного дослідження визначається тим, що вперше у вітчизняному мовознавстві предметом самостійного вивчення стала проблема стильового використання й стилістичної ролі обставин, виражених одиничними дієприслівниками й дієприслівниковими зворотами, а також функціонування вставних словосполучень, об'єднаних навколо дієприслівника. Розгляду піддані дієприслівники в складі фразеологізмів, оксиморонів, крилатих висловів, парцельованих конструкцій. Спостереження, висновки й узагальнення, які доповнюють теоретичні засади використання дієприслівникових структур у всіх стилях, виявляють поширеність кожної зі структур у стилях і підстилях української мови, обгрунтовують необхідність указувати в загальних курсах стилістики на жанрові відмінності текстів з ними і на їхню здатність задовольняти екстралінгвальні вимоги кожного функціонального різновиду мови. Їхнє загальностильове функціонування служить доказом для спростування думки про лише книжний їх характер. Проте, будучи загальностильовими елементами, дієприслівникові утворення неоднаково представлені у функціональних різновидах української мови: найвища частотність уведення в текст одиничних дієприслівників засвідчується в діалектному мовленні, а також у прислів'ях, які історично несуть у собі ознаки розмовно-побутового мовлення, меншою мірою вони представлені в художніх творах.

До відмінностей стилів слід віднести й уживаність / неуживаність фразеологізмів з дієприслівником в їхній основі. Вони чужі офіційно-діловому й науковому стилям, у інших засвідчуються в незначній кількості. Поділ стилів на підстилі й виявлення в них специфічних рис дають підстави стверджувати, що у визначенні стильових особливостей у загальних курсах стилістики недостатньо обмежуватися називанням лише найбільш характерних їхніх ознак. Необхідно вказувати на наявні в стилях підстилі з розкриттям 
істотних прикмет кожного з них. Наприклад, у загальних оглядах стилів традиційно вказується на трафаретність оформлення офіційно-ділових документів. Тим часом таке твердження справедливе лише щодо канцелярських паперів, частково дипломатичних угод, протоколів, пактів. Законодавчоправові акти, як підтверджує розглянутий у дисертації матеріал, найменшою мірою позначені трафаретним способом оформлення (Лисак, 2007). Нині Лариса Костянтинівна очолює кафедру гуманітарної підготовки Донбаської національної академії будівництва й архітектури.

Мариин Світлана Олександрівна - випускниця нашого університету. Після завершення навчання кілька років викладала українську мову та літературу в Дзержинському (Шевченківському) районі м. Харкова. Навчання в аспірантурі завершилося захистом дисертації на тему: «Нові явища у функціонально-стильовій диференціації безсполучникових складних речень в українській мові» (2007р.).

У цьому дослідженні вперше у вітчизняному мовознавстві було піддано розглядові стильову і стилістичну роль безсполучникових складних речень в аспекті їх функціонування в усіх стилях сучасної української мови, уперше поставлено завдання визначити приналежність кожного виду і підвиду цих структур до певних стилів, що дозволило встановити в них ознаки книжності й розмовності як стилістичних понять, а також виявити тенденції розвитку їхньої будови, меж і характеру функціонування. Результатом роботи стали здобуті (унаслідок аналізу стильової й стилістичної доцільності використання складних речень безсполучникового типу в певних сферах спілкування) спостереження й висновки, що доповнюють новими даними теоретичні засади безсполучниковості складних утворень і можуть бути використані в написанні підручників і навчальних посібників із синтаксису й стилістики української мови. Проведені спостереження засвідчують поширеність безсполучникових структур у всіх стилях української мови, що дає підстави стверджувати їхній загальностильовий характер; доводять їхню здатність задовольняти позалінгвальні вимоги кожного стилю нарівні зі сполучниковими реченнями; указують на розмежування в системі видів і підвидів розглядуваних речень специфічно розмовного і специфічно книжного плану. Усі ці дані, наголошено в роботі, служать вагомим підтвердженням реченнєвого характеру безсполучникових складних синтаксичних одиниць. Разом з тим у дисертації доведено, що складні речення безсполучникового типу беруть активну участь у взаємопроникненні стилів: у функціонуванні безсполучникових складних речень засвідчено посилений уплив офіційноділового, наукового і публіцистичного стилів на усне розмовне мовлення; помітною $є$ тенденція до залучення окремих безсполучникових утворень до науково-популярного викладу. Перелічені спостереження й висновки доводять, що розглянуті граматичні утворення, маючи етимологічне усномовне походження, виконують роль не тільки важливих одиниць синтаксичної будови сучасної української мови, а й функціонально активних стилістичних засобів текстотворення (Марцин, 2007). Світлана Олександрівна тривалий час працює на кафедрі українознавства ХНПУ імені Г. С. Сковороди. Вона 
завжди допомагала Сергієві Івановичу в оформленні його праць, була головним координатором усіх спільних справ аспірантів-дорошенківців. Колеги, жартуючи, називають пані Світлану секретарем професора Дорошенка.

До наймолодшого покоління аспірантів професора С. I. Дорошенка належить Карпенко Надія Олександрівна, яка працювала над темою «Структура, семантика і функції неподільних дієслівно-іменникових сполук у сучасній українській мові» (2009р.). Результати дослідження цієї роботи дають матеріал для поглибленого пізнання граматичної системи української мови, взаємодії ії синтетичної й аналітичної основи, сприяють подальшому розвитку теорії синтаксичних сполук. Спостереження й висновки становлять внесок в осмислення синтаксичних функцій активно вживаного явища, яке має тенденцію до розширення сфери використання, появи новотворів відповідно до екстралінгвальних потреб суспільства; розкривають багатовекторне використання цих сполук як стилістичного засобу. Запропонована в дисертації методика й опис функціонування неподільних дієслівно-іменникових сполук можуть бути використані для подальшого вивчення специфічних ознак структури, семантики, функцій і поширеності розглядуваних одиниць у кожному з підстилів функціональних різновидів сучасної української мови.

Репрезентовані в дисертації дані функціонування неподільних дієслівно-іменникових сполук у всіх стилях української мови дозволили внести уточнення щодо поширеності цих одиниць у різних сферах мовленнєвої діяльності; довести необгрунтованість твердження про їхню належність лише книжним і художньому стилям: у розмовно-побутовому мовленні вони такі ж природні, як і в текстах офіційно-ділових, наукових, публіцистичних чи художніх.

Обстеження різностильових джерел дозволило констатувати, що в розглядуваних поєднаннях задіяні не лише відзначувані в науковій літературі віддієслівні й власне абстрактні іменники, а й відприкметникові, віддієприкметникові іменники, які можуть трансформуватися як у дієслова й виступати в ролі присудка, так і перетворюватися на прикметник, дієприкметник чи прислівник, стаючи частиною відповідного складеного присудка. Дослідження розширило уявлення про синтаксичну роль неподільних дієслівноіменникових сполук, зокрема використання їх у функції простого дієслівного присудка, компонента складеного дієслівного присудка, головного члена безособового речення, додатка, неузгодженого означення, граматичноїоснови дієприслівникового звороту, головного члена інфінітивних, означено- й неозначено-особових речень. Використання розглядуваних сполук у всіх стилях сучасної української мови вказує і на їхню багатофункціональність як загальномовної синтаксичної одиниці, на здатність задовольняти специфічні вимоги кожного з функціональних різновидів мови, виявляючи при цьому своєрідність у типологічних ознаках (Карпенко, 2009). Надія Олександрівна зараз працює в науковому відділі ХНПУ імені Г. С. Сковороди.

Дисертація аспірантки Сергія Івановича з Одеси Барабаш Юлї̈ Георгї̈вни присвячена дослідженню складних речень із часовим відношенням предикативних частин, стала своєрідною «цеглиною» у створенні синтаксичної 
стилістики, потреб якої не можна задовольнити без вивчення стильової диференціації складних речень різних типів: складносурядних, складнопідрядних і безсполучникових. У ній у зіставному плані досліджено стильові й стилістичні функції структурно-семантичних різновидів складних речень із часовим відношенням предикативних частин як текстових компонентів художнього, публіцистичного, наукового й одного з підстилів офіційно-ділового стилю в періоди їх становлення й розвитку. Зокрема, аналіз функціювання досліджуваних конструкцій у різностильових текстах XIX - XXI ст. довів, що екстралінгвальні чинники, викликані розвитком освіти, науки, художньої літератури, розширенням ролі засобів масової інформації й зміцненням засад законодавства, вимагали відповідних суспільним потребам функцій української літературної мови й окреслення кола мовних одиниць кожного стилю, що й надало можливість авторові виділити ядерні й периферійні структури та часові сполучники на основі врахування їхньої частотності в різних сферах комунікації.

Представлені в дослідженні спостереження й висновки доповнюють теорію трьох типів складночасових речень: розширюють уявлення про їхню синтаксичну й стилістичну природу, про функції й частотність їх використання в книжних стилях української літературної мови; визначають динаміку стильової належності сполучних елементів складнопідрядних і складносурядних речень, зумовлену виробленням кодифікованих основ книжних текстів; подають нові відомості про поширеність складносурядних і складних безсполучникових речень із часовим відношенням у функціональних різновидах сучасної української літературної мови. Набуло подальшого розвитку осмислення потенційних можливостей складночасових речень бути стилістичним засобом у формуванні художнього тексту, наданні йому експресивності (Барабаш, 2010). Дисертація «Стильова диференціація складних речень із часовим відношенням» була захищена в 2010 році.

Мабуть, не було такої проблеми в мовознавстві, якою б не цікавився професор С. І. Дорошенко. Так сталося, що до керівництва роботою Книшенко Наталії Петрівни «Українська дорожньо-будівельна термінологія: структура і семантичні відношення» Сергій Іванович долучився на етапі опрацювання зібраного матеріалу. У дисертації вперше обгрунтовано самостійний статус дорожньо-будівельної терміносистеми як галузевої в межах спеціальної технічної термінології й репрезентовано цілісний опис системи специфічних і загальнонаукових термінів галузі дорожнього будівництва на основі теоретичних засад сучасного українського термінознавства. Виявлено основні ознаки структури й скласифіковано семантичні відношення iii компонентів, зокрема встановлено, що українська дорожньо-будівельна термінологія об'єднує чотири базові тематичні групи термінів на позначення: 1) теоретичних досліджень у галузі дорожнього будівництва; 2) дорожньо-будівельних матеріалів; 3) дорожньо-транспортних споруд; 4) засобів механізації для будівництва й ремонту автомобільних доріг. У межах української дорожньо-будівельної термінології виявлено тенденцію до впорядкування термінолексем за гніздовим принципом, при цьому основу гнізда 
часто становлять однослівні терміни, а відгалуження сформовані термінами словосполучного типу, засвідчуваними у вузькогалузевих і спільних з іншими технічними науками одиницях. Аспірантка уклала короткий тлумачний словник дорожньо-будівельної термінолексики, було окреслено тенденції розвитку української дорожньо-будівельної терміносистеми: повернення до життя питомо українських термінів, які в 50-80-х роках XX ст. були вилучені з ужитку; обмеження виявів внутрішньосистемної полісемії термінів завдяки кодифікації термінології й фіксуванню чітких дефініцій; посилення системоутворювальної сутності антонімів; зменшення кількості омонімічних форм, зокрема всередині системи; зменшення кількості лексичних синонімів, поширеність морфолого-синтаксичних синонімів (розвиток абревіації); активізація юкстапозиції й композиції як семантично ємних способів словотвору; збільшення кількості аналітичних термінів, що є свідченням поступового виформування виразної лексико-семантичної системності в межах дорожньо-будівельної термінології, яка здатна відбити системність наукових уявлень про дорожнє будівництво в новітніх умовах розвитку. Дослідження визначається тим, що виробленою в дисертації термінографічною репрезентацією досліджуваної галузі закладені теоретичні основи кодифікації й уніфікації терміноодиниць аналізованої терміносистеми, а також подані лінгвістичні рекомендації щодо нормалізації дорожньо-будівельної термінолексики на сучасному етапі (Книшенко, 2013).

Загалом до лінгвістичної царини професора С. І. Дорошенка належать i ті, хто впродовж свого професійного життя спілкувався, отримуючи від нього наукові консультації й життєві поради, допомогу, підтримку. Серед цих людей професори К. Ю. Голобородько, С. В. Ломакович, О. О. Маленко, О. М. Микитюк, О. А. Олексенко, П. О. Редін, доценти В. І. Бездітко, І. Є. Богданова, С. В. Вакуленко, Л. С. Загребельна, Л. Г. Пєнцова, Я. Ю. Сазонова, С. Б. Стасевський, I. В. Тимченко, усі члени рідної кафедри та багато інших колег й однодумців, для яких Сергій Іванович був надійним другом, Учителем і наставником.

\section{ЛІТЕРАТУРА}

1. Алексеюк М. И. Предикативные наименования лиц в современном украинском языке: автореф. дисс. ... канд. филол. наук: спец. 10.02.02. «украинский язык». Харьков: ХГУ, 1988. 23 с. 2. Барабаш Ю. Г. Стильова диференціація складних речень із часовим відношенням: : автореф. дис. ... канд. філол. наук: спец. 10.02.01. «українська мова». Харків: ХНПУ, 2010. 20 с. 3. Беценко Т. П. Структура і поетичні функції атрибутивних словосполучень у поезіях шістдесятників: автореф. дис. ... канд. філол. наук: спец. 10.02.01. «українська мова». Харків: ХДПУ, 1999. 20 с. 4. Бєляєва Т. В. Варіантність і синонімія в умовно-наслідкових складних реченнях: автореф. дис. ... канд. філол. наук: спец. 10.02.01. «українська мова». Харків: ХДПУ, 2004. 20 с. 5. Ващенко О. І. Валентна і невалентна сполучуваність відприкметникових іменників у сучасній українській мові: автореф. дис. ...канд. філол. наук: спец. 10.02.01. «українська мова». Харків: ХДПУ, 2005. 20 с. 6. Гамова А. И. Синтаксическое выражение цели в современном украинском литературном языке: автореф. дисс. ... канд. филол. наук: спец.10.02.02. «украинский язык». Харьков: ХГУ, 1989. 24 с. 7. Глотова О. В. Функціонально-синтаксичний аналіз категорії причиновості в сучасній українській літературній мові: 
автореф. дис. ... канд. філол. наук: спец. 10.02.02. «українська мова». Харків: ХДПУ, 1994. 16 с. 8. Загревський Є. І. Безсполучникові складні речення з пояснювальним компонентом у сучасній українській мові: автореф. дис. ... канд. філол. наук: спец. 10.02.01. «українська мова». Харків: ХДПУ, 1999. 20 с. 9. Карпенко Н. О. Структура, семантика і функції неподільних дієслівно-іменникових сполук у сучасній українській мові: автореф. дис. ... канд. філол. наук: спец. 10.02.01. «українська мова». Харків: ХНПУ, 2009. 20 с. 10. Книшенко Н. П. Українська дорожно-будівельна термінологія: структура і семантичні відношення: автореф. дис. ... канд. філол. наук: спец. 10.02.01. «українська мова». Харків: ХНПУ, 2013. 20 с. 11. Кринська Н. В. Семантико-синтаксична категорія наслідку в складному реченні у книжних стилях сучасної української мови: Автореф.дис. ... канд. філол. наук: спец.: 10.02.01. «українська мова». Харків: ХДПУ, 2001. 16 с. 12. Лисак Л. К. Синтаксико-стилістичні функції речень 3 дієприслівником у стилях сучасної української мови: автореф. дис. ... канд. філол. наук: спец. 10.02.01. «українська мова». Харків: ХНПУ, 2007. 20 с. 13. Марцин С. О. Нові явища у функціонально-стильовій диференціації безсполучникових складних речень в українській мові: автореф. дис. ... канд. філол. наук: спец. 10.02.01. «українська мова». Харків: ХНПУ, 2007. 20 с. 14. Мясоєдова С. В. Категорія спонукання і іiі вираження в непрямих висловленнях сучасної української мови: автореф. ...канд. філол. наук: спец. 10.02.01. «українська мова». Харків: ХДПУ, 2001. 19 с. 15. Олійник С. П. Осмислене письмо за зразком як засіб формування правописних навичок у першокласників: автореф. ... канд. пед. наук: спец. 13.00.02. Харків: ХДПУ, 1995. 24 с. 16. Степул О. Л. Безсполучникові складні речення із значенням зіставності і протиставності в українській мові: автореф. дис. ...канд. філол. наук: спец. 10.02.02. «українська мова». Харків: ХДПУ, 1992. 20 с. 17. Тєлєжкіна О. О. Безсполучникові складні речення з компонентом обгрунтування: автореф. дис. ... канд. філол. наук: спец. 10.02.01. «українська мова». Харків: ХДПУ, 2002. 18 с. 18. Черновол-Ткаченко Р. І. Формування орфографічної грамотності з української мови в російськомовних першокласників: автореф. дис. ... канд. пед. наук: спец. 13.00.02. Харків: ХДПУ, 1995. 24 с. 19. Чернушенко Н. М. Безсполучникові умовно-наслідкові речення в функціонально-синтаксичному аспекті: автореф. дис. ... канд. філол. наук: спец. 10.02.02. «українська мова». Харків: ХДПУ, $1995.29 \mathrm{c}$.

\section{REFERENCES}

1. Alekseyuk, M. I. (1988). Predikativnyie naimenovaniya lits v sovremennom ukrainskom yazyike [Predictive names of persons in modern Ukrainein language] Extended abstract of candidate's thesis. Kharkiv: KhDU [in Ukrainian]. 2. Barabash, Yu. G. (2010). Stilova diferentsiatsiya skladnih rechen iz chasovim vidnoshennyam [Stylistic differentiation of complex sentences with time relation] . Extended abstract of candidate's thesis. Kharkiv: KhDPU [in Ukrainian]. 3. Betsenko, T. P. (1999). Struktura i poetichni funktsiyi atributivnih slovospoluchen u poeziyah shistdesyatnikiv [Structure and poetic functions of attribute phrasesin poetry of the sixties] Extended abstract of candidate's thesis. Kharkiv: KhDPU [in Ukrainian]. 4. Belyaeva, T. V. (2004). Variantnist i sinonimiya v umovno-naslidkovih skladnih rechennyah: [Variance and synonymy in conditional-consequential complex regressions] Extended abstract of candidate's thesis. Kharkiv: KhDPU [in Ukrainian]. 5. Vaschenko, O. I. (2005). Valentna i nevalentna spoluchuvanist vidprikmetnikovih imennikiv u suchasniy ukrayinskiy movi [ Valence and nonvalent connectivity from the exemplarynouns in modern Ukrainian]. Extended abstract of candidate's thesis. Kharkiv: KhDPU [in Ukrainian]. 6. Gamova, A. I. (1989). Sintaksicheskoe vyirazheniye tseli v sovremennom ukrainskom literaturnom yazyike [Syntactic expression of the goal in the modern Ukrainian literary language]. Extended abstract of candidate's thesis. Kharkiv: KhDU [in Ukrainian]. 7. Glotova, O. V. (1994). Funktsionalnosintaksichniy analiz kategoriyi prichinovosti v suchasniy ukrayinskiy lIteraturniy movi [Functional-syntactic analysis of the causality category in modern Ukrainian literary language] 
Extended abstract of candidate's thesis. Kharkiv: KhDPU [in Ukrainian]. 8. Zagrevskiy, E. I. (1999). Bezspoluchnikovi skladni rechennya z poyasnyuvalnim komponentom u suchasniy ukrayinskiy movi [Uncompromising complex sentences with an explanatory component in the modern Ukrainian language]. Extended abstract of candidate's thesis. Kharkiv: KhDPU [in Ukrainian]. 9. Karpenko, N. O. (2009). Struktura, semantika i funktsiyi nepodilnih dieslivnoimennikovih spoluk u suchasniy ukrayinskiy movi [Structure, semantics and functions of indivisible verbally-nouns in modern Ukrainian]. Extended abstract of candidate's thesis. Kharkiv: KhDPU [in Ukrainian]. 10. Knishenko, N. P. (2013). Ukrayinska dorozhno-budivelna terminologiya: struktura i semantichni vidnoshennya [Ukrainian road-building terminology: structure and semantic relation]. Extended abstract of candidate's thesis. Kharkiv: KhDPU [in Ukrainian]. 11. Krinska, N. V. (2001). Semantiko-sintaksichna kategoriya naslidku V skladnomu rechenni u knizhnih stilyah suchasnoyi ukrayinskoyi movi: spets [Semanticsyntactic succession category in a complex sentence in the book styles of modern Ukrainian language]. Extended abstract of candidate's thesis. Kharkiv: KhDPU [in Ukrainian]. 12. Lisak, L. K. (2007). Sintaksiko-stiiIstichni funktsiyi rechen z dieprislivnikom u stilyah suchasnoyi ukrayinskoyi movi [Syntactic-stylistic functions of sentences with an adverb in the styles of modern Ukrainian]. Extended abstract of candidate's thesis. Kharkiv: KhNPU [in Ukrainian]. 13. Martsin, S. O. (2007). Novi yavischa u funktsionalno-stiloviy diferentsiatsiyi bezspoluchnikovih skladnih rechen $\mathrm{v}$ ukrayinskiy movi: nauk [New phenomena in the functional-style differentiation of uncompromising complex sentences in the Ukrainian language]. Extended abstract of candidate's thesis. Kharkiv: KhNPU [in Ukrainian]. 14. Myasoedova, S. V. (2001). Kategoriya sponukannya i yiyi virazhennya $\mathrm{v}$ nepryamih vislovlennyah suchasnoyi ukrayinskoyi movi [Category of motivation and its expression in the indirect expressions of modern Ukrainian language]. Extended abstract of candidate's thesis. Kharkiv: KhDPU [in Ukrainian]. 15. Oliynik, S. P. (1995). Osmislene pismo za zrazkom yak zasib formuvannya pravopisnih navichok $\mathrm{u}$ pershoklasnikiv [A meaningful letter on the model as a means of forming spelling skills in first-graders]. Extended abstract of candidate's thesis. Kharkiv: KhDPU [in Ukrainian]. 16. Stepul, O. L. (1992). Bezspoluchnikovi skladni rechennya iz znachennyam zistavnosti i protistavnosti $\mathrm{v}$ ukrayinskiy movi [Uncompromising complex sentences with the meaning of comparability and contrast in the Ukrainian language]. Extended abstract of candidate's thesis. Kharkiv: KhDPU [in Ukrainian]. 17. Telezhkina, O. O. (2002). Bezspoluchnikovi skladni rechennya $\mathrm{z}$ komponentom obgruntuvannya [Uncompromising complex sentences with a justification component]. Extended abstract of candidate's thesis. Kharkiv: KhDPU [in Ukrainian]. 18. Chernovol-Tkachenko, R. I. (1995). Formuvannya orfografIchnoyi gramotnosti z ukrayinskoyi movi v rosiyskomovnih pershoklasnikiv [Formation of spelling literacy from the Ukrainian language in Russian-speaking first-graders]. Extended abstract of candidate's thesis. Kharkiv: KhDPU [in Ukrainian]. 19. Chernushenko, N. M. (1995). Bezspoluchnikovi umovno-naslidkovi rechennya $\mathrm{v}$ funktsIonalno-sintaksichnomu aspekti [Unconditional conditional-consequence sentences in a functional-syntactic aspect]. Extended abstract of candidate's thesis. Kharkiv: KhDPU [in Ukrainian].

Чернушенко Ніна Миколаївна - кандидат філологічних наук, доцент, доцент кафедри теорії і методики викладання філологічних дисциплін у початковій школі, Харківський національний педагогічний університет імені Г.С. Сковороди; вул. Валентинівська, 2, м. Харків, 61168, Україна.

Tel.: +38-067-58-79-795

E-mail: nina.chernushenko@gmail.com

https://orcid.org/

Chernushenko Nina Mykolaivna - PhD in Philology, Associate Professor, Department of Theory and Methodology of Teaching Philological Disciplines in Elementary School, H. S. Skovoroda Kharkiv National Pedagogical University; Valentynivska Str., 2, Kharkiv, 61168, Ukraine.

Надійшла до редакції 13 лютого 2019 року 